\title{
HUBUNGAN JUMLAH LEUKOSIT DENGAN KEJADIAN SINDROM SYOK DENGUE (SSD) PADA ANAK DI RUMAH SAKIT UMUM DAERAH Dr. H. ABDUL MOELOEK BANDAR LAMPUNG
}

\author{
Devita Febriani Putri1), Tusy Triwahyuni²) \\ 1Departemen Parasitologi, Fakultas Kedokteran, Universitas Malahayati \\ Email : devita@malahayati.ac.id \\ 2Departemen Parasitologi, Fakultas Kedokteran, Universitas Malahayati \\ tusitriwahyuni@malahayati.ac.id
}

\begin{abstract}
Dengue Hemorrhagic Fever is still a dengue virus infection world health problems. Platelets and haemotocrit are one of the indicators assessed in depth DHF laboratory examination, while leukopenia is a frequent marker of syok found in the dengue disease is still often ignored in the diagnosis of DHF.

To find out the relationship between the number of leukocytes and SSD in children in RSUD dr. H. Abdul Moeloek Bandar Lampung in 2017.

This study is a retrospective study with a cross sectional study design. Subject The study was children who were diagnosed with DHF, and performed routine blood tests at the Dr. Hospital. H. Abdoel Moeloek Bandar Lampung during 2017. Data was obtained from medical records by analysis using the chi-square statistical test. The total sample obtained by 35 children suffered from dengue with 24 of them experience SSD.

The results of the research analysis stated that there were significant differences between the number of leukocytes in children with SSD compared to children who did not experience SSD $(P=0.026)$. Children with DHF with leukopenia has a higher risk of experiencing SSD 13.1 compared with children with DHF without leukopenia.

There is a positive relationship between leukocyte count and the incidence of dengue shock syndrome in children with dengue fever in RSUD dr. H. Abdul Moeloek Bandar Lampung.
\end{abstract}

Keyword: leucosyt, SSD, dengue, children

\section{ABSTRAK}

Demam Berdarah Dengue merupakan penyakit infeksi virus dengue yang masih menjadi masalah kesehatan dunia. Trombosit dan haemotokrit menjadi salah satu indikator yang dinilai dalam pemeriksaan laboratorium DBD, sedangkan leukopenia merupakan salah satu penanda syok yang sering ditemukan dalam perjalanan penyakit DBD masih sering diabaikan dalam diagnosis DBD.

Mengetahui hubungan jumlah leukosit dengan SSD pada anak di RSUD dr. H.Abdul Moeloek Bandar Lampung Tahun 2017.

Penelitian ini merupakan studiretrospektif dengan rancangan studi cross sectional.Subyek penelitian adalah anak-anak yang didiagnosis DBD, dan melakukan pemeriksaan darah rutin di RSUDDr. H.Abdoel Moeloek Bandar Lampung selama tahun 2017. Data didapatkan dari rekam medik dengan analisis menggunakan uji statistic chi-square. Total sampel yang didapat 35 anak menderita DBD dengan 24 diantaranya mengalami SSD.

Hasil analisis penelitian menyatakan terdapat perbedaan bermakna antara jumlah leukosit pada anak penderita SSD dibandingkan anak yang tidak mengalami SSD $(P=0.026)$. Penderita $D B D$ anak dengan leukopenia memiliki resiko mengalami SSD lebih tinggi 13,1 dibandingkan dengan penderita DBD anak tanpa leukopenia.

Terdapat hubungan positif antara jumlah leukosit dengan kejadian sindroma syok dengue pada anak penderita DBD di RSUD dr.H. Abdul Moeloek Bandar Lampung.

Kata Kunci: leukosit, SSD, dengue, anak 


\section{PENDAHULUAN}

Demam Berdarah Dengue (DBD) adalah penyakit infeksi oleh virus dengue dengan manifestasi klinis demam, nyeri otot, nyeri sendi yang disertai leukopenia, ruam, limfadenopati, trombositopenia dan perdarahan(Setiati et al., 2014). Infeksi DBD dapat berkembang menjadi renjatan Sindrom Syok Dengue (SSD) yang berakibat fatal bila tidak ditangani secara baik dan tepat. Diagnosis dini dan perawatan yang tepat diharapkan dapat mengurangi risiko kematian akibat syok(Diana, 2007).

DBD dan SSD masih menjadi perhatian utama masalah kesehatan internasional dengan perkiraan 500.000 kasus di rawat di rumah sakit, dan sedikitnya 2,5\% meninggal(WHO, 2005). World Health Organization (WHO) memperkirakan 50 juta orang terinfeksi DBD setiap tahunnya dengan prevalensi SSD sebesar 5-7 \%. Pada negara berkembang, Incidence Rate (IR) atau angka kesakitan penyakit ini berfluktuatif setiap tahunnya, denganCase Fatality Rate (CFR) atau angka kematian berkisar $1-2,5 \%$, yang artinya setiap 100 kasus DBD sekitar 1-3 orang meninggal dunia karena penyakit DBD (Wilder et al., 2005).

Negara Indonesia dilaporkan 112.511 kasus infeksi DBD pada tahun 2014, dengan IR sebanyak 45.85 per 100.000 dan CFR sebanyak $0,71 \%$ atau 871 orang. Angka prevalensi SSD sebanyak 1-2 \% dari angka IR yang dilaporkan per 100.000 penduduk. Peningkatan jumlah kasus terjadi pada tahun 2014 dibandingkan tahun 2013 sebesar 90.245 kasus dengan IR sebanyak 37,27 $\%$.Provinsi Bali menduduki IR tertinggi pada tahun 2014 sebanyak 204 kasus per 100.000 penduduk(Kemenkes RI, 2014).

Dinas Kesehatan Provinsi Lampung menyatakan IR penyakit DBD di Provinsi Lampung pada tahun 2014 sebanyak 27 kasus per 100.000 penduduk,sedangkan prevalensi SSD di provinsi Lampung sebanyak 0,8 \% per 100.000 kasus infeksi demam dengue. Kota Bandar Lampung merupakan kota dengan IR tertinggi bila dibandingkan dengan daerah lainnya. Data tahun 2014 di Kota Bandar Lampung, dari 13 kecamatan yang ada, seluruhnya dinyatakan endemis DBD, dan dari 98 Kelurahan, tercatat 86 Kelurahan yang endemis DBD. Total IR DBD dari tahun 2004 2014 berfluktuatif. Tahun 2007 terjadi lonjakan kasus, tercatat IR per 100.000 penduduk sebesar 235 kasus, meningkat tajam dari tahun 2006 yang hanya sebesar 109 kasus. Lonjakan kasus selanjutnya terjadi di tahun 2014 dengan IR sebesar 179 kasus, meningkat hampir $400 \%$ dari tahun sebelumnya yang hanya sebesar 47 kasus. Peningkatan IR kasus DBD yang terjadi di tahun
2007 dan 2014 ini dinilai sangat signifikan, dan penyebab utamanya belum diketahui(Dinkes Provinsi Lampung, 2014).

Penatalaksaan yang baik dan penerapan deteksi dini infeksi virus dengue dapat menurunkan CFR sebelum dekade 2000(WHO, 2011). Penatalaksanaan DBD pada rawat inap dirumah sakit biasanya menggunakan nilai trombosit dan hematokrit sebagai indikator perkembangan penyakit selain mafestasi klinis pasien. Leukopenia atau rendahnya jumlah leukosit dibandingkan normalsering kali ditemukan dalam perjalanan penyakit DBD, namunmasih diabaikan dalam diagnosis DBD.Leukopenia adalah pertanda dalam 24 jam kemudian demam akan turun dimana pasienmasuki masa kritis. Masa kritis pada DBD berkisar antara 48-72 jam, yang biasanya terjadi pada hari ke 4-5 dengan masa penyembuhan yang cepat dan tanpa gejala sisa, seperti pada syok septik(Ristiani et al., 2011).

Penelitian sebelumnya tentang hubungan jumlah leukosit dengan kejadian SSD sudah dilakukan oleh Ristiani et al. (2011)diRSPI Prof. dr. Sulianti Saroso (RSPI-SS) Jakarta,menyimpulkan bahwahasil pemeriksaan laboratorium menunjukkan kasus DBD dengan leukopenia berisiko 2,1 kali lebih besar mengalami SSD dibandingkan yang tidak leukopenia. Penelitian Dewi et al. (2006) menyatakan bahwa SSD dengan leukopenia beresiko lebih rendah 0.8 kali dibandingkan dengan pasien yang tidak mengalami leukopenia. Penelitian lain dilakukan oleh Agilatun (2007)di RSUP Dr. Kariadi Semarang menyimpulkanbahwa tidak terdapat hubungan leukopenia dengan SSD. Berdasarkan uraian latar belakang, serta hasil penelitian yang berbeda maka tujuan dari penelitian untuk menganalisis lebih mendalam tentanghubungan jumlah leukosit dengan SSD pada anak di RSUD.H.Abdul Moeloek Bandar Lampung.

\section{METODE PENELITIAN}

Metode penelitian adalah analitik retrospektif dengan rancangan studi cross sectional. Penelitian dilakukan diinstalasi rekam medis RSUD dr. $\mathrm{H}$. Abdul Moeloek Bandar Lampung. Populasi penelitian yaitu pasien telah terdiagnosis penyakit demam berdarah dengue dan mengalami stadium sindroma syok dengue, pasien dengan pemeriksaan imunologi $\operatorname{lgM}$ atau pemeriksaan serologi NS1 positif dan anak laki - laki serta perempuan berumur 0-15 tahun.Sampelpenelitian adalah pasien infeksi demam berdarah dengue (DBD) dan telah dilakukan pemeriksaan darah rutin di RSUD dr. H.Abdoel Moeloek Bandar Lampung tahun 2017. Data yang dipergunakan merupakan data sekunder rekam medis yang didapatkan dari 
instalasi rekam medis RSUD dr. H. Abdul Moeloek, mencakup karakteristik pasien, pasien yang terdiagnosa demam berdarah dengue mengalami tahap sindroma syok dengue, dan terdapat lampiran hasil pemeriksaan darah rutin pada rekam medis.
HASIL PENELITIAN DAN PEMBAHASAN

Analisis Univariat Karakteristik Pasien Demam

Berdarah Dengue di Bangsal Anak, RSUDdr.H.

Abdul Moeloek Bandar lampung.

Tabel 1 Karakteristik Pasien Demam Berdarah Dengue Berdasarkan Jenis Kelamin, Kelompok umur, Jenis Pemeriksaan, dan Derajat Klinis

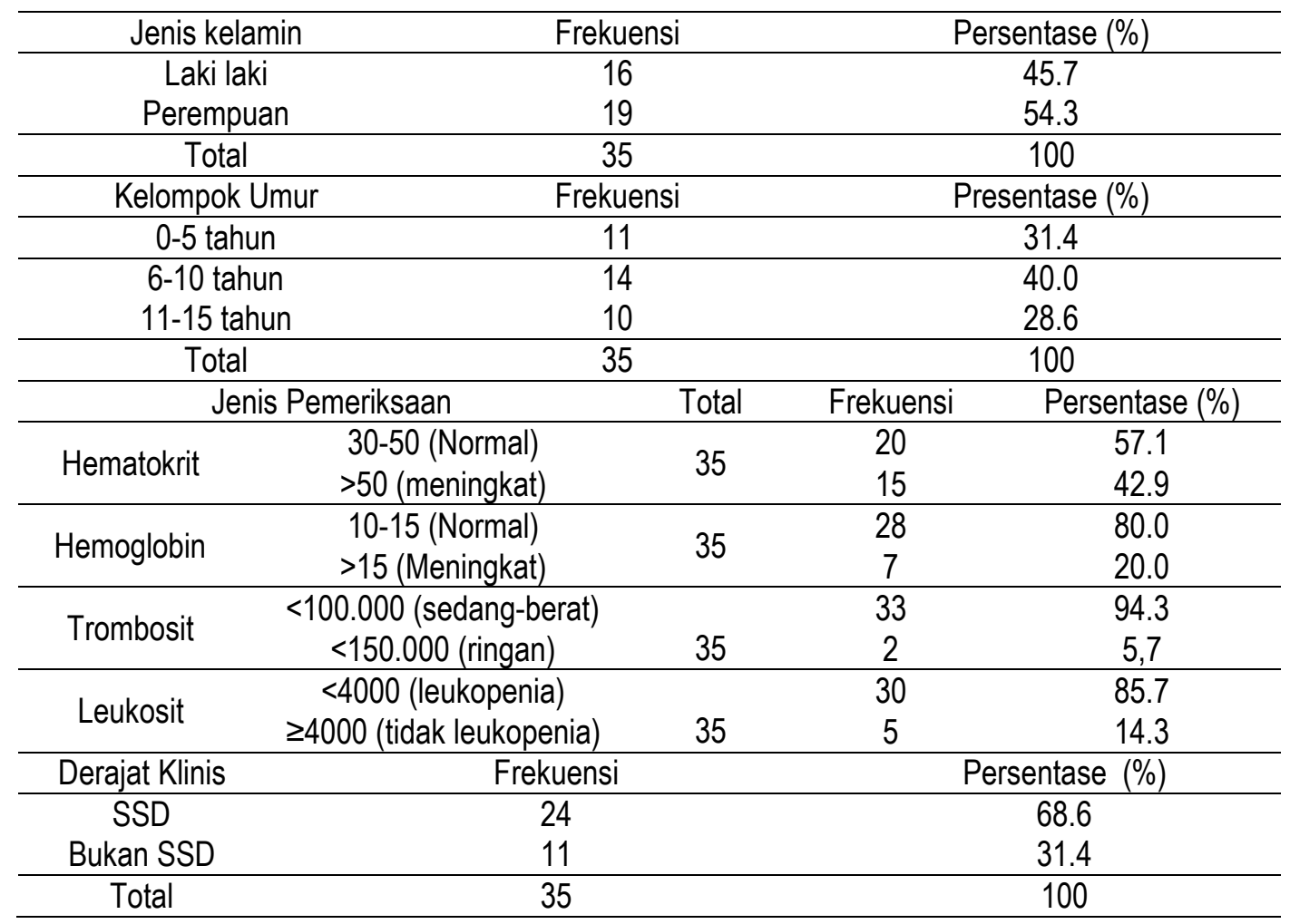

Data rekam medis pada periode tahun 2017 didapatkan 35 pasien yang dapat dijadikan sampel penelitian, sesuai dengan kriteria inklusi. Analisis univariat dilakukan berdasarkan karakteristik jenis kelamin, kelompok umur, jenis pemeriksaan dan derajat klinis (Tabel 1). Sebanyak 16 pasien anak berjenis kelamin laki - laki (45.7\%) dan pasien anak perempuan berjumlah 19 orang $(54.3 \%)$. Berdasarkan karakteristik umur, kasus terbanyak pada pasien berusia 6-10 tahun sebanyak 40 orang (40\%) kemudian pasien berusia 0-5 tahun sebanyak 11 orang (31.4\%), diikuti usia 11-15 tahun sebanyak 10 orang pasien (28.6\%). Tabel 1 juga memperlihatkan distribusi frekuensi dari nilai hematokrit, nilai hematokrit pada sebagian sampel mengalami peningkatan pada 15 pasien $(42.9 \%)$, nilai hemoglobin pada kebanyakan sampel berada dalam batas normal dan hanya sedikit nilai hemoglobin yang mengalami peningkatan yaitu 7 pasien $(20 \%)$. Berdasarkan jenis pemeriksaan nilai trombosit hampir semua sampel mengalami trombositopenia dengan derajat $<100.000$ (sedang- berat) sebanyak 33 pasien (94.3\%) dan jumlah leukosit pada pasien DBD yang mengalami leukopenia (jumlah leukosit < 4000)sejumlah 30 pasien $(85.7 \%)$.

Analisis Bivariat Hubungan Jumlah Leukosit dengan Kejadian Sindroma Syok Dengue (SSD) Pada Anak di RSUD Dr.H Abdul Moeleok Bandar Lampung

Hasil dari analisis bivariat(tabel 2)menunjukkan pasien DBD yang mengalamiSSD dengan jumlah leukosit < 4000 (leukopenia) sebanyak 23 orang $(76.7 \%)$, dan jumlah leukosit $\geq 4000$ (tidak mengalami leukopenia) sebanyak 1 orang $(20 \%)$. Pasien DBD yang tidak mengalamiSSD dengan jumlah leukosit $<4000$ sebanyak 7 orang (23.3\%), dan jumlah leukosit $\geq 4000$ sebanyak 4 orang $(80 \%)$. Hasil penelitian mengindikasikan ada hubungan positif antara jumlah hubungan jumlah leukosit dengan kejadian SSD pada anak di RSUD dr. H. Abdul Moeleok Bandar Lampung tahun $2017 \quad(p=0.026)$. Pasien 
yang mengalami leukopenia akan beresiko mengalami SSD 13.143 kali lebih besar dibandingkan dengan yang tidak mengalami leukopenia $(O R=13.143)$.

Tabel 2 Hubungan Leukopenia dengan Kejadian Sindroma Syok Dengue (SSD) Pada Anak di RSUD Dr.H Abdul Moeleok Bandar Lampung

\begin{tabular}{|c|c|c|c|c|c|}
\hline \multirow{2}{*}{$\begin{array}{c}\text { Nilai } \\
\text { Leukosit }\end{array}$} & \multicolumn{2}{|c|}{ Derajat Demam Berdarah } & \multirow{2}{*}{ Total } & \multirow{2}{*}{ P-value } & \multirow{2}{*}{ OR } \\
\hline & SSD & Bukan SSB & & & \\
\hline$<4000$ & 23 & 7 & 30 & \multirow{2}{*}{0,026} & \multirow{2}{*}{13.143} \\
\hline$\geq 4000$ & 1 & 4 & 5 & & \\
\hline Total & 24 & 11 & 35 & & \\
\hline
\end{tabular}

\section{PEMBAHASAN}

Hasil analisis univariat karakteristik pasien DBD di Bangsal Anak, RSUDDr.H. Abdul Moeloek Bandar Lampung (Tabel 1) memperlihatkansampel penderita DBD berdasarkan usia, paling banyak diderita oleh anak berusia 0-5 tahun dan 6-10 tahun dibandingkan anak berusia $>10$ tahun.Umumnya pasien DBD dibawah 10 tahun memiliki derajat keparahan yang cenderung tinggi, dimana semakin muda umur pasien diikuti dengan semakin banyak kematian yang terjadi. Kemungkinan yang terjadi sel endotel pembuluh kapiler pada anak lebih rentan terjadi pelepasan sitokin sehingga terjadi peningkatan permeabilitas kapiler.Selain itu perbedaan ini kemungkinan karena pada awal transmisi DBD umumnya terjadi di rumah namun saat ini telah beralih ke fasilitas publik seperti sekolah,mesjid, gereja dan tempat bermain anakanak.SSD lebih sering terjadi pada anak dengan status gizi yang baik dan imunokompeten, sangat jarang terjadi pada anak malnutrisi(Raihan et al , 2016).

Distribusi frekuensi dari nilai hematokritmeningkat pada sebagian sampel (Tabel 1). Peningkatan nilai hematokrit atau hemokonsentrasi merupakan indikator terjadinya kebocoran plasma. Nilai hematokrit biasanya mulai meningkat pada hari ketiga dan makin meningkat sesuai dengan proses perjalanan penyakit demam berdarah.Proses kebocoran plasma ke ruang ekstravaskular disertai dengan efusi cairan serosa, melalui kapiler yang rusak.Akibat yang terjadi volume plasma menjadi berkurang yang menyebabkan syok hipovolemik dan kegagalan sirkulasi (Rena et al. 2009). Nilai hemoglobin pada sebagian sampel juga mengalamipeningkatan (Tabel 1). Kadar hemoglobin pada haripertama biasanya normal atau sedikit menurun, tetapi kemudian kadarnya akan meningkat mengikuti peningkatan hemokonsentrasi.Naiknya kadar hemoglobin merupakan penanda diagnosis DBD yang paling awal ditemukan (Aryati, 2012)(Lee et al., 2012).
Distribusi frekuensi nilai trombosit memperlihatkan semua pasien anak mengalami trombositopenia (Tabel 1). Trombositopenia merupakan keadaan penurunan jumlah trombosit dibawah normal yaitu< $100.000 \mathrm{~mm}^{3}$ yang merupakan salah satu kriteria diagnosis pasti DBD. Keadaan trombositopenia terjadi pada demam di hari ketiga sampai ke delapan, umumnya terjadi sebelum ada peningkatan hematokrit. Mekanisme terjadinya trombositopenia pada demam berdarah bersifat multifaktorial, tiga teori yang menjelaskan keadaan trombositopenia pada DBD adalah penurunan jumlah trombosit akibat supresi sumsum tulang, meningkatnya destruksi trombosit dan pemakaian jumlah trombosit yang berlebih(Rena et al. 2009)(Noiksan dan Perng,2010).Leukopenia terjadi pada sebagian besar pasien yang mengalami SSD (Tabel 1), karena pada pasien SSD terjadi kebocoran plasma yang luas dibandingkan dengan pasien DBD yang tidak mengalami SSD. Pada saat kebocoran plasma terjadi sangat luas pada endotel pembuluh darah,akan terjadi migrasi leukosit yang diaktivasi dari aliran darah ke jaringan inflamasi. Leukopenia dijumpai hari pertama dan ketiga dengan hitung jenis. Jumlah granulosit menurun pada hari ke 3 8 , dan sering ditemukannya limfosit bertransformasi atau atipik (Ristiani et al., 2011)(Soedarto, 2005).

Berdasarkan hasil penelitian didapatkan ada hubungan positif jumlah leukosit dengan kejadian SSD pada anak di RSUD Dr.H. Abdul Moeleok Bandar Lampung. Hasil penelitian ini sesuai dengan penelitian Ristiani et al.(2011)yang menyebutkan hasil pemeriksaan laboratorium menunjukkan penderita DBDanak dengan leukopenia berisiko 2,1 kali lebih besar mengalami SSD dibandingkan yang tidak leukopenia. Penelitian ini juga sesuai dengan teori leukopenia sering terjadi pada pasien SSD, yang disebabkan migrasi leukosit yang diaktivasi dari aliran darah ke jaringan endotel yang mengalami inflamasi, dimana pada SSD endotel pembuluh darah mengalami inflamasi lebih luas. 
Pasien DBD akan mengalami SSD, bila kebocoran plasma terjadi dalam jumlah yang lebih dari $30 \%$ volume darah, sehingga pasien akan kekurangan cairan dan tanda syok mulai muncul. Disfungsi endotel (sel yang terdapat pada permukaan pembuluh darah) dengan manifestasi klinis berupa peningkatan permeabililitas vaskuler yang bertanggung jawab pada kebocoran plasma. Gangguan vaskuler terjadi ketika leukosit melekat pada endotel, menyebabkan teraktivasinya endotel, netrofil, dan limfosit, oleh sitokin yang dikeluarkan monosit/makrofag. Sitokin atau mediator inflamasi yang disekresikan oleh Sel monosit dan makrofag adalah interleukin-1 (IL-1), IL-6, tumor necrosis factor (TNF) alfa dan platelet activating factor (PAF). Faktor tersebut dapat menyebabkan efek multiple terhadap endotel, yaitu menekan aktivitas anti-koagulan, memacu pro-koagulan, dan meningkatkan permeabilitas vaskuler. Pada DBD maupun SSD, jejas pada endotel terjadi akibat pembentukan kompleks imun (virus dan antibody)yang akanmengaktivasi sistem komplemen. Sistem komplemen akan mengsekresikan $\mathrm{C} 3 \mathrm{a}$ dan $\mathrm{C5a}$ yang juga mengakibatkan peningkatan permeabilitas vaskuler. Aktivasi sel endotel tidak terjadi secara langsung tetapi melalui faktor-faktor yang dikeluarkan akibat monosit yang terinfeksi oleh virus dengue. Pelekatan trombosit oleh matriks sub-endotelial, menyebabkan leukosit juga akan melekat. Netrofil yang merupakan salah satu komponen leukosit dan trombosit masing-masing mengeluarkan faktorfaktor yang saling mengaktifkan satu sama lain. Pada penderita DBD menunjukkan peningkatan 4integrin-dependent yang dapat meningkatkan perlekatan sel pada pembuluh darah. Salah satu kelainan klinis yang terjadi akibat perlekatan ini adalah septik syok. (Soegijanto, 2006) (Rena et al, 2009) (Adams dan Nash, 1996).

Teori yang sering digunakan untuk menjelaskan perubahan patogenesis pada DBD dan SSD yaitu hipotesis infeksi sekunder (teori secondary heterologous infection) atau teori $A D E$ (antibody independent enhancement). Hipotesis infeksi sekunder menyebutkan apabila seseorang terkena infeksi primer dengan satu jenis virus, maka akan terjadi proses kekebalan terhadap infeksi jenis virus tersebut untuk jangka waktu yang lama, karena memiliki antibodi yang menetralisasi infeksi jenis virus tersebut. Infeksi berat akan terjadi jika orang tersebut terkena infeksi sekunder dengan jenis serotipe virus yang lain, karena pada infeksi selanjutnya antibody heterologous yang telah terbentuk dari infeksi primer akan membentuk kompleks dengan virus baru dengan serotipe yang berbeda bahkan membentuk kompleks infeksius yang berkembang menjadi DBD atau DSS. Sedangkan teori ADE menyatakan bahwa antibody timbul justru mempercepat replikasi monosit atau makrofag. (Clyde et al., 2006) .

Keterbatasan dalam penelitian ini data yang didapatkan berupa rekam medis, peneliti tidak melakukan wawancara secara langsung terhadap pasien dikarenakan waktu penelitian yang tidak memungkinkan. Sehingga teori tentang pathogenesis SSD akibat infeksi sekunder DBD pada pasien belum dapat dibuktikan. Selain itu peneliti mengalami kendala terutama dalam proses pengumpulan data sampel. Data rekam medis pasien DBD banyak yang hilang karena pindahnya ruangan penyimpanan rekam medis RSUD dr. $H$. Abdul Moeleok ke gedung lain. Hal ini menyebabkan sampel pasien SSD yang dibutuhkan untuk penelitian didapatkan hanya sedikit sedangkan kelengkapan dan ketersediaan data rekam medis menjadi kualitas dalam penelitian ini.

\section{SIMPULAN}

Jumlah leukosit berhubungan bermakna $(P=$ 0.026) dengan kejadian SSD pada anak di RSUD Dr.H Abdul Moeleok Bandar Lampung Tahun 2017.Penderita DBD anak dengan leukopenia memiliki resiko mengalami SSD lebih tinggi 13,1 dibandingkan dengan penderita DBD anak tanpa leukopenia. Leukopenia pada pasien DBD anak didukung dengan peningkatan haemotokrit, haemoglobin, dan semua pasien anak mengalami trombositopenia.

\section{DAFTAR PUSTAKA}

Adams, D. H., \& Nash, G. B. (1996). Disturbance of leucocyte circulation and adhesion to the endothelium as factors in circulatory pathology. British journal of anaesthesia, 77(1), 17-31.

Agilatun, N. (2007). Hubungan antara Jumlah Leukosit dengan Kejadian Syok pada Penderita Demam Berdarah Dengue Dewasa di RSUP DR. Kariadi Semarang (Doctoral dissertation, Faculty of Medicine).

Aryati. (2017). Buku Ajar Demam Berdarah Dengue Edisi 2 Tinjauan Laboratoris. Surabaya: Airlangga University Press.

Clyde, K., Kyle, J. L., \& Harris, E. (2006). Recent advances in deciphering viral and host determinants of denque virus replication and pathogenesis. Journal of virology, 80(23), 11418-11431.

Dewi, R., Tumbelaka, A. R., \& Sjarif, D. R. (2006). Clinical features of dengue hemorrhagic fever and risk factors of shock 
event. Paediatrica Indonesiana, 46(3), 1448.

Diana, M. (2007). Korelasi Antara Trombositopenia dengan Hemokonsentrasi Sebagai Faktor Predisposisi Terjadinya Syok pada Pasien Demam Berdarah Dengue Dewasa di RSUP Dr. Kariadi Semarang (Doctoral dissertation, Faculty of Medicine).

Dinas Kesehatan Provinsi lampung. (2014). Profil Kesehatan Provinsi lampung 2014. Diakses dari https://dinkes.lampungprov.go.id.

Kementerian Kesehatan, R. I. (2014). Profil kesehatan indonesia. Diakses dari http://www. kemkes. go. id.

Lee, Y. R., Liu, M. T., Lei, H. Y., Liu, C. C., Wu, J. M., Tung, Y. C., ... \& Liu, H. S. (2006). MCP-1, a highly expressed chemokine in dengue haemorrhagic fever/dengue shock syndrome patients, may cause permeability change, possibly through reduced tight junctions of vascular endothelium cells. Journal of General Virology, 87(12), 3623-3630.

Noisakran, S., \& Perng, G. C. (2008). Alternate hypothesis on the pathogenesis of dengue hemorrhagic fever (DHF)/dengue shock syndrome (DSS) in dengue virus infection. Experimental biology and medicine, 233(4), 401-408.

Raihan, R., Hadinegoro, S. R. S., \& Tumbelaka, A. R. (2016). Faktor prognosis teriadinya syok pada demam berdarah dengue. Sari Pediatri, 12(1), 47-52.
Rena, N. M. R. A., Utama, S., \& Parwati, T. (2009). Kelainan hematologi pada demam berdarah dengue. Jurnal Penyakit Dalam, 10(3), 218-225.

Risniati, Y., Tarigan, L. H., \& Tjitra, E. (2011). Leukopenia Sebagai Prediktor Teriadinya Sindrom Syok Dengue Pada Anak Dengan Demam Berdarah Dengue Di Rspi. Prof. Dr. Sulianti Saroso. Media Penelitian dan Pengembangan Kesehatan, 21(3).

Setiati, S., Alwi, I., Sudoyo, A. W., Simadibrata, M., Setiyohadi, B., \& Syam, A. F. (2014). Buku ajar ilmu penyakit dalam. Jakarta: Interna Publishing.

Soedarto. (2012). Demam Berdarah Dengue Dengue Haemorrhagic Fever. Jakarta: Sagung Seto.

Soegijanto, S. (2006). Demam Berdarah Dengue Edisi 2. Surabaya: Airlangga University Press.

World Health Organization. (2005). Dengue, dengue haemorrhagic fever and dengue shock syndrome in the context of the integrated management of childhood illness (No. WHO/FCH/CAH/05.13). Geneva: World Health Organization.

World Health Organization. (2011). Comprehensive guideline for prevention and control of denque and denque haemorrhagic fever.

Wilder-Smith, A., Chen, L. H., Massad, E., \& Wilson, M. E. (2009). Threat of dengue to blood safety in dengue-endemic countries. Emerging infectious diseases, 15(1), 8. 